\title{
Pediatric Nutrition in Practice
}





\section{Pediatric Nutrition in Practice}

Editor

Berthold Koletzko Munich

Co-Editors

Peter Cooper Johannesburg

Maria Makrides North Adelaide

Cutberto Garza Boston, Mass.

Ricardo Uauy Santiago de Chile

Weiping Wang Shanghai 


\section{Berthold Koletzko}

University of Munich

Dr. von Hauner Children's Hospital

Lindwurmstr. 4

DE-80337 Munich (Germany)

\section{Peter Cooper}

Department of Paediatrics

University of the Witwatersrand \&

Johannesburg Hospital

Johannesburg 2000 (South Africa)

Maria Makrides

Child Nutrition Research Centre

University of Adelaide

Women's \& Children's Hospital

72 King William Road

North Adelaide, S.A. 5006 (Australia)

\section{Ricardo Uauy}

INTA

University of Chile

Casilla 138-11

Santiago de Chile (Chile)

\section{Weiping Wang}

Fudan University

138 Yi Xue Yuan Road

200032 Shanghai (China)

\section{Cutberto Garza}

Boston College

Chestnut Hill, MA 02467 (USA)

Library of Congress Cataloging-in-Publication Data

Pediatric nutrition in practice / editor, Berthold Koletzko ; co-editors,

Peter Cooper ... [et al.].

$$
\text { p. ; } \mathrm{cm} \text {. }
$$

Includes bibliographical references and indexes.

ISBN 978-3-8055-8477-7 (soft cover : alk. paper)

1. Children--Nutrition--Handbooks, manuals, etc. I. Koletzko, B.

(Berthold) II. Cooper, Peter, 1951 Sept. 12-

[DNLM: 1. Child Nutrition Physiology. WS 130 P3713 2008]

RJ206.P3635 2008

$618.92--\mathrm{dc} 22$

2008023394

Disclaimer. The statements, options and data contained in this publication are solely those of the individual authors and contributors and not of the publisher and the editor(s). The appearance of advertisements in the book is not a warranty, endorsement, or approval of the products or services advertised or of their effectiveness, quality or safety. The publisher, the editor(s) and Nestlé Nutrition Institute disclaim responsibility for any injury to persons or property resulting from any ideas, methods, instructions or products referred to in the content.

Drug Dosage. The authors and the publisher have exerted every effort to ensure that drug selection and dosage set forth in this text are in accord with current recommendations and practice at the time of publication. However, in view of ongoing research, changes in government regulations, and the constant flow of information relating to drug therapy and drug reactions, the reader is urged to check the package insert for each drug for any change in indications and dosage and for added warnings and precautions. This is particularly important when the recommended agent is a new and/or infrequently employed drug.

All rights reserved. No part of this publication may be translated into other languages, reproduced or utilized in any form or by any means electronic or mechanical, including photocopying, recording, microcopying, or by any information storage and retrieval system, without permission in writing from the publisher.

(c) Copyright 2008 by S. Karger AG, P.O. Box, CH-4009 Basel (Switzerland)

www.karger.com

Printed in Switzerland on acid-free paper by Reinhardt Druck, Basel

ISBN 978-3-8055-8477-7 


\section{Contents}

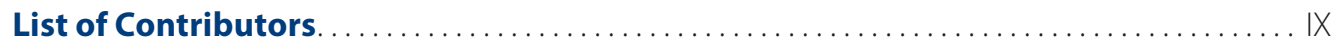

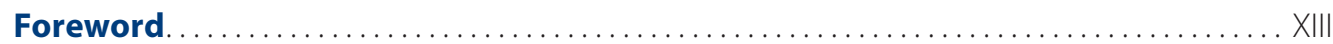

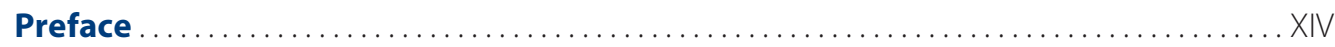

1 General Aspects of Childhood Nutrition

1.1 Child Growth

Kim Fleischer Michaelsen ............................................... 1

1.2 Nutritional Assessment

1.2.1 Clinical Evaluation and Anthropometry

John W.L. Puntis

1.2.2 History and Dietary Intake

Roxana Valdes-Ramos.

1.2.3 Use of Technical Measurements in Nutritional Assessment

Hillary Burdette $\cdot$ Babette Zemel $•$ Virginia A. Stallings. . . . . . . . . . . . . . . . . . . . . . . . . . . 17

1.2.4 Use of Laboratory Measurements in Nutritional Assessment

Ryan Himes ${ }^{2}$ Robert Shulman................................................. 21

1.3 Nutritional Needs

1.3.1 Nutrient Intake Values: Concepts and Applications

Berthold Koletzko. . . . . . . . . . . . . . . . . . . . . . . . . . . . . . . . . . . . . . . . . . . . . . . . . 27

1.3.2 Energy Requirements of Infants, Children and Adolescents

Nancy Butte ........................................................ 31

1.3.3 Protein

Paul Pencharz • Rajavel Elango ............................................... 37

1.3.4 Digestible and Indigestible Carbohydrates

C. Lawrence Kien ....................................................... 42

1.3.5 Fats

Patricia Mena $\cdot$ Ricardo Uauy ............................................... 47

1.3.6 Fluid and Electrolytes

George J. Fuchs..................................................... 52 
1.3.7 Vitamins and Trace Elements

Noel Solomons ........................................................... 57

1.4 Physical Activity: Impact on Child Health and Nutritional Needs

Robert M. Malina. .....................................................62

1.5 Early Nutrition and Long-Term Health

Berthold Koletzko................................................ 67

1.6 Food Safety

Hildegard Przyrembel. ............................................... 71

1.7 Gastrointestinal Development, Nutrient Digestion and Absorption

Michael J. Lentze. ..................................................... 76

1.8 Gut Microbiota in Infants

Seppo Salminen $•$ Mimi Tang ............................................... 80

$2 \quad$ Nutrition of Healthy Infants, Children and Adolescents

2.1 Breastfeeding

Kim Fleischer Michaelsen ................................................. 85

2.2 Formula Feeding

Dominique Turck ...................................................... 90

2.3 Marketing of Breast-Milk Substitutes

Vinodini Reddy ....................................................... 98

2.4 Complementary Foods

Mary Fewtrell ..................................................... 102

2.5 Allergy Prevention through Early Nutrition

Sibylle Koletzko ..................................................... 106

2.6 Toddlers, Pre-School and School Children

Hildegard Przyrembel..................................................... 110

2.7 Adolescence

Luis A. Moreno. ............................................................... 114

2.8 Challenges in Transition from Childhood to Adult Age in Low Income Populations

Mauro Fisberg • Marcia Vitolo • Mara Andréa Valverde.

2.9 Food Choices, Cultural Influences and Nutrition Transition -

A Japanese Perspective

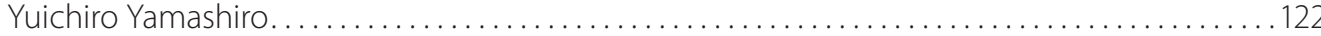

2.10 Nutrition in Pregnancy and Lactation

Renate L. Bergmann $•$ Karl E. Bergmann....................................... 125

$2.11 \quad$ Vegetarian Diets

Jules Tolboom .

$3 \quad$ Nutritional Challenges in Special Conditions and Diseases

3.1 Primary and Secondary Undernutrition

Kraisid Tontisirin • Lalita Bhattacharjee.

3.2 Iron Deficiency and Other Nutrient Deficiencies

Noel W. Solomons 
3.4 Parenteral Nutrition Support

Berthold Koletzko. ...

3.5 Overweight and Obesity

Martin Wabitsch

3.6 Acute and Chronic Diarrhea

Zulfiqar Bhutta.

3.7 HIV and AIDS

Haroon Saloojee • Peter Cooper..................................................... 162

3.8 Cholestatic Liver Diseases

Edmond Rings ..................................................... 168

3.9 Malabsorptive Disorders and Short Bowel Syndrome

Olivier Goulet.

3.10 Celiac Disease

Stefano Guandalini. . .

3.11 Food Intolerance and Allergy

Ralf G. Heine

3.12 Regurgitation and Gastroesophageal Reflux

Tejas Mehta $•$ Benjamin Gold . . . . . . ................................................ 191

3.13 Feeding Disorders

Richard M. Katz . .

3.14 Preterm and Low Birthweight Infants

Ekhard E. Ziegler

3.14.1 Feeding the Low Birthweight Infant in a Resource-Restricted Environment

Fredrick N. Were .204

3.15 Diabetes Mellitus and Inborn Errors of Metabolism

Hansjosef Böhles........................................................... 208

3.16 Hypercholesterolemia

Berthold Koletzko.......................................................... 214

3.17 Enteral Nutrition in Inflammatory Bowel Disease

Anne M. Griffiths $•$ Megan Carricato ................................................. 219

3.18 Nutrition in Cystic Fibrosis

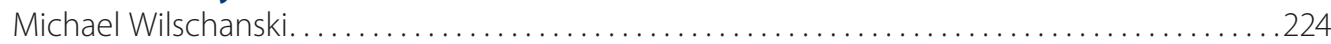

3.19 Heart Disease

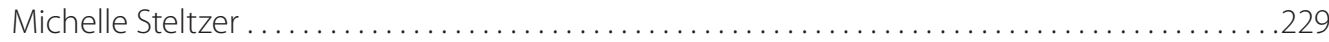

3.20 Renal Disease

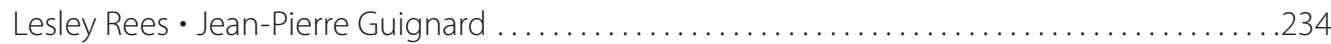

3.21 Anorexia Nervosa and Bulimia Nervosa

Ascensión Marcos................................................................239

3.22 Hemato-Oncology

3.23 Intensive Care

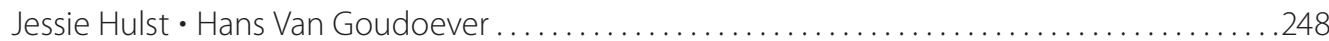


$4 \quad$ Annex

4.1 The WHO Child Growth Standards

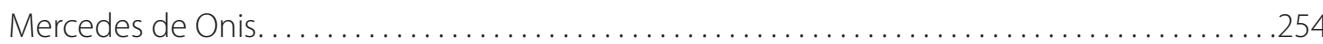

4.2 The CDC and Euro Growth Charts

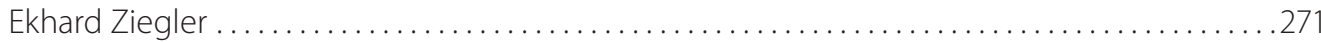

4.3 Reference Nutrient Intakes for Infants, Children and Adolescents

Berthold Koletzko • Maria Hermoso . . . . . . . . . . . . . . . . . . . . . . . . . . . . . . . . . . . . . . . . . . . . . 285

4.4 Feeding My Baby - Advice for Families

Berthold Koletzko • Katharina Dokoupil. . . .

4.5 Increasing Dietary Energy and Nutrient Supply

Berthold Koletzko • Katharina Dokoupil.

$5 \quad$ Index

Author Index.

.298

Subject Index 


\section{List of Contributors}

\section{Karl E. Bergmann}

Departments of Pediatrics and Obstetrics

Charité University Medicine Berlin

Augustenburger Platz 1

DE-13353 Berlin (Germany)

E-Mail karl.bergmann@charite.de

\section{Renate L. Bergmann}

Departments of Pediatrics and Obstetrics Charité University Medicine Berlin

Augustenburger Platz 1

DE-13353 Berlin (Germany)

E-Mail renate.bergmann@charite.de

\section{Lalita Bhattacharjee}

National Food Policy Capacity Strengthening Programme Food and Agriculture Organization of the United Nations House 37, Road 8, Dhanmondi R/A

Dhaka 1205 (Bangladesh)

E-Mail Lalita.Bhattacharjee@fao.org

\section{Zulfiqar Ahmed Bhutta}

Husein Lalji Dewraj Professor \& Chairman Department of Paediatrics \& Child Health Aga Khan University

Karachi 74800 (Pakistan)

E-Mail zulfiqar.bhutta@aku.edu

\section{Hansjosef Böhles}

Department of Pediatrics

Zentrum für Kinder- und Jugendmedizin

Johann Wolfgang Goethe University

Theodor Stern Kai 7

DE-60590 Frankfurt-am-Main (Germany)

E-Mail hansjosef.boehles@kgu.de

\section{Nancy F. Butte}

USDA/ARS Children's Nutrition Research Center

Baylor College of Medicine

1100 Bates Street

Houston, TX 77030 (USA)

E-Mail nbutte@bcm.edu

\section{Megan Carricato}

Gastroenterology, Hepatology \& Nutrition

The Hospital for Sick Children

555 University Avenue

Toronto, Ont. M5G 1X8 (Canada)

E-Mail megan.carricato@sickkids.ca

\section{Peter Cooper}

Department of Paediatrics

University of the Witwatersrand \& Johannesburg Hospital Private Bag X39

Johannesburg 2000 (South Africa)

E-Mail peter.cooper@wits.ac.za

\section{Mercedes de Onis}

Department of Nutrition

World Health Organization

Avenue Appia 20

CH-1211 Geneva 27 (Switzerland)

E-Mail deonism@who.int

\section{Katharina Dokoupil}

University of Munich

Dr. von Hauner Children's Hospital

Lindwurmstrasse 4

DE-80337 Munich (Germany)

E-Mail katharina.dokoupil@med.uni-muenchen.de

\section{Rajavel Elango}

Physiology and Experimental Medicine Division

Research Institute

The Hospital for Sick Children

Toronto, Ont. M5G 1X8 (Canada)

E-Mail rajavel.elango@sickkids.ca

\section{Mary Fewtrell}

Childhood Nutrition Research Centre

UCL Institute of Child Health

30 Guilford Street

London WC1N 1EH (UK)

E-Mailm.fewtrell@ich.ucl.ac.uk 


\section{Mauro Fisberg}

Federal University of Sao Paulo

Nutrition Center, Sao Marcos University

Rua Botucatu 715, Vila Clementino

04023-062 Sao Paulo (Brazil)

E-Mail fisberg@uol.com.br

\section{George J. Fuchs}

Departments of Pediatric Gastroenterology, Hepatology and Nutrition

University of Arkansas for Medical Sciences

Mail stop 512-7

4301 West Markham Street

Little Rock, AR 72205 (USA)

E-Mail fuchsgeorgej@uams.edu

\section{Benjamin D. Gold}

Division of Pediatrics and Microbiology,

Pediatric Gastroenterology, Hepatology and Nutrition

Emory University School of Medicine

2015 Uppergate Drive NE

Atlanta, GA 30322 (USA)

E-Mail ben_gold@oz.ped.emory.edu

\section{Olivier Goulet}

Hôpital Necker - Enfants Malades

149 Rue de Sèvres

FR-75743 Paris Cedex 15 (France)

E-Mail olivier.goulet@nck.ap-hop-paris.fr

\section{Anne M. Griffiths}

Hospital for Sick Children

555 University Avenue

Toronto, Ont. M5G 1X8 (Canada)

E-Mail anne.griffiths@sickkids.ca

\section{Stefano Guandalini}

Pediatric Gastroenterology, MC 4065

University of Chicago

5839 South Maryland Avenue

Chicago, IL 60637 (USA)

E-Mailsguandalini@peds.bsd.uchicago.edu

\section{Jean-Pierre Guignard}

Lausanne University Medical School

CHUV-BP 11

CH-1011 Lausanne (Switzerland)

E-Mail Jean-Pierre.Guignard@chuv.ch

\section{Ralf G. Heine}

Department of Gastroenterology \& Clinical Nutrition Royal Children's Hospital, Melbourne

University of Melbourne

Parkville, Vic. 3052 (Australia)

E-Mail ralf.heine@rch.org.au

\section{Maria Hermosa}

University of Munich

Dr. von Hauner Children's Hospital

Lindwurmstrasse 4

DE-80337 Munich (Germany)

E-Mailmaria.hermosa@med.uni-muenchen.de

\section{Ryan W. Himes}

Section of Pediatric Gastroenterology

Texas Children's Hospital

Baylor College of Medicine

6621 Fannin St, CCC 1010.00

Houston, TX 77030 (USA)

E-Mail himes@bcm.tmc.edu

\section{Jessie M. Hulst}

Department of Pediatrics

Sophia Children's Hospital

Erasmus Medical Center

PO Box 2060

NL-3000 CB Rotterdam (The Netherlands)

E-Mail j.hulst@erasmusmc.nl

\section{Richard M. Katz}

Mount Washington Pediatric Hospital

1708 West Rogers Avenue

Baltimore, MD 21209 (USA)

E-Mail rkatz@jhmi.edu

\section{Craig Lawrence Kien}

E203 Given Medical Building, Given Room C417

University of Vermont

89 Beaumont Avenue

Burlington, VT 05405 (USA)

E-Mail cl.kien@uvm.ed

\section{Sanja Kolaček}

Department of Pediatrics

Children's Hospital Zagreb

Referral Center for Pediatric Gastroenterology \& Nutrition

Klaićeva 16

CRO-10000 Zagreb (Croatia)

E-Mail sanja.kolacek@kdb.hr

\section{Berthold Koletzko}

University of Munich

Dr. von Hauner Children's Hospital

Lindwurmstrasse 4

DE-80337 Munich (Germany)

E-Mail office.koletzko@med.uni-muenchen.de

\section{Sibylle Koletzko}

University of Munich

Dr. von Hauner Children's Hospital

Lindwurmstrasse 4

DE-80337 Munich (Germany)

E-Mail sibylle.koletzko@med.uni-muenchen.de 
Michael J. Lentze

Zentrum für Kinderheilkunde

University of Bonn

Adenauerallee 119

DE-53113 Bonn (Germany)

E-Mail michael.lentze@ukb.uni-bonn.de

\section{Ascensión Marcos}

Immunonutrition Research Group

Department Metabolism and Nutrition

Instituto del Frío C/José Antonio Novais, 10

ES-28040 Madrid (Spain)

E-Mail amarcos@if.csic.es

\section{Robert M. Malina}

10735 FM 2668

Bay City, TX 77414 (USA)

E-Mail rmalina@skyconnect.net

\section{Tejas R. Mehta}

Divison of Pediatric Gastroenterology,

Hepatology and Nutrition

Emory University School of Medicine

2015 Uppergate Dr., NE

Atlanta, GA 30322 (USA)

E-Mail tejas_mehta@oz.ped.emory.edu

\section{Patricia Mena}

INTA, University of Chile

Casilla 138-11

Santiago de Chile (Chile)

E-Mailpmena@inta.cl

\section{Kim Fleischer Michaelsen}

Departments of Paediatric Nutrition

and Human Nutrition, Faculty of Life Sciences

University of Copenhagen

Rolighedsvej 30

DK-1958 Frederiksberg C (Denmark)

E-Mail kfm@life.ku.dk

\section{Luis A. Moreno}

Escuela Universitaria de Ciencias de la Salud

Universidad de Zaragoza

C/Domingo Miral $s / n$

ES-50009 Zaragoza (Spain)

E-Mail Imoreno@unizar.es

\section{Paul B. Pencharz}

Departments of Paediatrics and Nutritional Sciences Division of Gastroenterology, Hepatology and Nutrition Hospital for Sick Children

555 University Avenue

Toronto, Ont. M5G 1X8 (Canada)

E-Mail paul.pencharz@sickkids.ca

\section{Hildegard Przyrembel}

Federal Institute for Risk Assessment

Thielallee 88-92

DE-14195 Berlin (Germany)

E-Mail hildegard.przyrembel@bfr.bund.de
John W.L. Puntis

Department of Gastroenterology

Room 142 B Floor, Clarendon Wing

General Infirmary at Leeds

Belmont Grove

Leeds LS2 9NS (UK)

E-Mail john.puntis@leedsth.nhs.uk

\section{Vinodini Reddy}

Nutrition Consultant

503 Mount Meru Apt.

Banjara Hills, Road No. 5

Hyderabad 500034 (India)

E-Mail vinodinireddy@hotmail.com

\section{Lesley Rees}

Renal Office

Gt Ormond St Hospital for Sick Children NHS Trust

Gt Ormond Street

London WC1N 3JH (UK)

E-Mail REESL@gosh.nhs.uk

\section{Edmond H.H.M. Rings}

Department of Pediatrics

Beatrix Children's Hospital

University Medical Center

University of Groningen

POB 30.001

NL-9700 RB Groningen (The Netherlands)

E-Mail e.h.h.m.rings@bkk.umcg.nl

\section{Seppo Salminen}

Functional Food Forum

University of Turku

FN-20014 Turku (Finland)

E-Mail seppo.salminen@utu.fi

\section{Haroon Saloojee}

Department of Paediatrics

University of the Witwatersrand \&

Johannesburg Hospital

Private Bag X39

Johannesburg 2000 (South Africa)

E-Mail haroon.saloojee@wits.ac.za

\section{Robert J. Shulman}

Children's Nutrition Research Center

1100 Bates Avenue, CNRC 8072

Houston, TX 77030 (USA)

E-Mail rshulman@bcm.tmc.edu

\section{Noel W. Solomons}

Scientific Director

CeSSIAM

17a Avenida Marisca No. 16-89, Zona 11

Guatemala City, 01011 (Guatemala)

E-Mail cessiam@guate.net.gt 


\section{Virginia A. Stallings}

Division of Gastroenterology, Hepatology and Nutrition

Children's Hospital of Philadelphia

34th and Civic Center Blvd.

Philadelphia, PA 19104 (USA)

E-Mail Stallingsv@email.chop.edu

\section{Michelle M. Steltzer}

Department of Pediatrics

Division of Pediatric Cardiology

Children's Hospital of Wisconsin

Herma Heart Center

Medical College of Wisconsin

8701 Watertown Plank Road

Milwaukee, WI 53226 (USA)

E-Mail michelle3970@verizon.net

\section{Mimi Tang}

Department of Allergy and Immunology

Royal Children's Hospital

Melbourne (Australia)

E-Mailmimi.tang@rch.au

\section{Jules J.M. Tolboom}

Paediatric Gastro-Enterologist

Principal Consultant in Paediatrics

Radboud University Medical Centre, 833

University Medical Centre St Radboud, 833

POB 9101

NL-6500 HB Nijmegen (The Netherlands)

E-Mail j.tolboom@cukz.umcn.nl

\section{Kraisid Tontisirin}

Institute of Nutrition

Mahidol University Salaya

Nakhon Pathom 73170 (Thailand)

E-Mail kraisid.tontisirin@gmail.com

\section{Dominique Turck}

Unité de Gastro-Entérologie, Hépatologie et Nutrition

Clinique de Pédiatrie

Hôpital Jeanne de Flandre

2, avenue Oscar Lambret

FR-59037 Lille (France)

E-Maildturck@chru-lille.fr

\section{Ricardo Uauy}

INTA Santiago

Santiago de Chile (Chile)

E-Mail uauy@inta.cl

\section{Roxana Valdes-Ramos}

Facultad de Medicina

Universidad Autonoma del Estado de Mexico

Jesus Carranza esq. Paseo Tollocan

Col. Moderna de la Cruz

50180, Toluca, Edo. Mex. (Mexico)

E-Mail rycramos@uaemex.mx

\section{Mara Andréia Valverde}

Applied Human Nutrition

University of São Paulo

R. Nilo, 241 apto: 52 Aclimação

01533-010 São Paulo SP (Brazil)

E-Mail mara.valverde@uol.com.br

\section{Johannes B. van Goudoever}

Division of Neonatology, Department of Pediatrics Sophia Children's Hospital

Erasmus Medical Center

POB 2060

NL-3000 CB Rotterdam (The Netherlands)

E-Mail j.vangoudoever@erasmusmc.nl

\section{Marcia Regina Vitolo}

Public Health Department/Nutrition

Universidade Federal de Ciências da Saúde de

Porto Alegre (UFCSPA)

Rua Sarmento Leite 245

90050-170 Porto Alegre RS (Brazil)

E-Mailvitolo@ufcspa.edu.br

\section{Martin Wabitsch}

Division of Pediatric Endocrinology

Diabetes and Obesity Unit

Department of Pediatrics and Adolescent Medicine

University of Ulm

Eythstrasse 24

DE-89075 Ulm (Germany)

E-Mail martin.wabitsch@uniklinik-ulm.de

\section{Fredrick N. Were}

Department of Paediatrics

University of Nairobi

Kenyatta National Hospital Campus

POB 20956-00202

Nairobi (Kenia)

E-Mail frednwere@yahoo.co.uk

\section{Michael Wilschanski}

Pediatric Gastroenterology and Nutrition Unit

Hadassah University Hospitals

Jerusalem (Israel)

E-Mail michaelwil@hadassah.org.il

\section{Yuichiro Yamashiro}

Probiotic Research Laboratory Juntendo University Graduate School of Medicine 3rd Floor, 2-9-8 Hongo, Bunkyo-ku

Tokyo 113-0033 (Japan)

E-Mail yamasiro@med.juntendo.ac.jp

\section{Ekhard E. Ziegler}

Department of Pediatrics

University of lowa

A-136 MTF, 2501 Crosspark Road

Coralville, IA 52241-8802 (USA)

E-Mail ekhard-ziegler@uiowa.edu 


\section{Foreword}

The Nestlé Nutrition Institute (NNI) was created to provide healthcare professionals with up-todate information on nutrition and nutrition-related disorders in order to promote health for children and adults, in particular those who have specific needs, based on the latest medical and scientific breakthroughs.

For more than 60 years the NNI has contributed to the continuing nutrition education of health professionals. NNI's activities comprise live events (e.g. congresses, workshops), written publications, online programs, audio, video, or other electronic media. The vast majority of information is also available online at www.nestlenutrition-institute.org.

Pediatric Nutrition in Practice is a handbook comprising all relevant, practical reference information for the feeding of generally healthy infants, children and adolescents, and for nutritional care in pediatric diseases. It is intended to be used by pediatricians working in preventive and curative services around the world, including both high- and low-income settings. The content of this book will also be transformed into an accredited e-learning course, available online at www.nestlenutrition-institute.org, which will further increase its utility for pediatricians.

The NNI is deeply indebted to the editor of this book, Prof. Bert Koletzko from the University of Munich, Germany, for his outstanding work in establishing and coordinating the content of $\mathrm{Pe}$ diatric Nutrition in Practice. We also wish to warmly thank the co-editors, Prof. Peter Cooper, Johannesburg, South Africa; Dr. Maria Makrides, Adelaide, Australia; Prof. Ricardo Uauy, Santiago de Chile, Chile; Prof. Cutberto Garza, Boston, Mass., USA, and Prof. Weiping Wang, Shanghai, China, for their great contribution to the preparation of this book.

Prof. Ferdinand Haschke, MD, PhD Chairman, Nestlé Nutrition Institute Vevey, Switzerland Dr. Petra Klassen, PhD Dr. Denis Barclay, PhD Nestlé Nutrition Institute Vevey, Switzerland 


\section{Preface}

There is no other time in life when the provision of appropriate nutrition is of greater importance than during infancy and childhood. During this phase of life characterized by rapid growth and development, an adequate amount and composition of substrates both in health and disease are of key importance for growth, functional outcomes such as cognition and immune response, and long-term wellbeing. While a number of excellent textbooks on pediatric nutrition are available that provide detailed accounts on the scientific and physiologic basis of nutrition as well as its application, busy physicians and other healthcare professionals often find it difficult to devote sufficient time to study elaborate and extensive books on just one aspect of their practice. Therefore, we decided to develop this compact reference book to provide concise information to readers who seek quick guidance on practical relevant issues in the nutrition of infants, children and adolescents. This book was developed with a truly international perspective to address challenges both in affluent and poorer populations, which could only be achieved with the insightful input of a global editorial board. I wish to thank my co-editors very much indeed for their enthusiastic help and support in developing this project. I am also most grateful to the authors from all parts of the world, who are renowned experts in their fields, for their willingness to dedicate their knowledge, time and effort in preparing their chapters. It has been a great pleasure to work with the editorial production team at Karger Publishers, who did a fantastic and very professional job in producing a book of outstanding quality. Finally, I gratefully acknowledge the generous financial support of the Nestlé Nutrition Institute that covered a large portion of the production costs and will help to widely disseminate this practical guide. With sincere thanks I also wish to highlight the fact that the Nestlé Nutrition Institute and its representatives Petra Klassen-Wigger, Denis Barclay and Ferdinand Haschke supported the editors in making their fully independent choices on content, direction and the authors of this book, and this is greatly appreciated indeed.

It is the sincere hope of the editors that this book will be useful to many healthcare professionals around the world, and that it may contribute to further enhancing the quality of feeding for healthy infants and children, as well as enhancing the standards of nutritional care for sick children. We are very keen to have feedback on this book from you, the readers, including suggestions on which aspects might be improved even further in the future. Thank you very much for your support!

Berthold Koletzko, Munich

E-Mail office.koletzko@med.uni-muenchen.de 